Article

\title{
Identification and Analysis of Structural Fund Support Mitigating the Effects of the COVID-19 Pandemic in the EU-A Case Study of Health Unit Funding
}

\author{
Karina Bedrunka ${ }^{1}$, Łukasz Mach ${ }^{2, *} \mathbb{\infty}$, Anna Kuczuk ${ }^{3} \mathbb{D}$ and Anna Bohdan ${ }^{2}$ \\ 1 Department of Coordination of Operational Programs, Marshal Office of Opolskie Voivodship, Krakowska 38, \\ 45-075 Opole, Poland; karbed74@gmail.com \\ 2 Faculty of Economics and Management, Opole University of Technology, Luboszycka 7, 45-036 Opole, \\ Poland; a.bohdan@po.edu.pl \\ 3 Faculty of Mechanical Engineering, Opole University of Technology, Mikołajczyka 5, 45-271 Opole, Poland; \\ a.kuczuk@po.edu.pl \\ * Correspondence: 1.mach@po.edu.pl
}

Citation: Bedrunka, K.; Mach, Ł.; Kuczuk, A.; Bohdan, A. Identification and Analysis of Structural Fund Support Mitigating the Effects of the COVID-19 Pandemic in the EU-A Case Study of Health Unit Funding. Energies 2021, 14, 4976. https:// doi.org/10.3390/en14164976

Academic Editor: Ligita Šimanskienè

Received: 29 June 2021

Accepted: 11 August 2021

Published: 13 August 2021

Publisher's Note: MDPI stays neutral with regard to jurisdictional claims in published maps and institutional affiliations.

Copyright: (c) 2021 by the authors. Licensee MDPI, Basel, Switzerland. This article is an open access article distributed under the terms and conditions of the Creative Commons Attribution (CC BY) license (https:/ / creativecommons.org/licenses/by/ $4.0 /)$.

\begin{abstract}
The research carried out describes the provision of COVID-19 funding in individual EU Member States under the ongoing operational programmes of the EU financial perspective in the period 2014-2020. This was followed by identification of the most important areas of support and the amounts allocated to them for Poland and its sixteen voivodeships under the available EU funds from the 2014-2020 perspective. Types and forms of support for health services from the funds of the Regional Operational Programme for the Opolskie Voivodeship 2014-2020 (ROP WO) were analysed in detail. The obtained results showed that Italy, Spain, and Poland provided the largest values of support under the available operational programmes from 2014-2020 to combat the effects of COVID19. In Poland, funding was mainly provided by the European Regional Development Fund, with the dominant support allocated to entrepreneurship and health care. In the Opolskie voivodeship, which is the case study, the additional financing in the health area concerns: personal protective equipment, equipment, construction works, oxygen installations, and waste water management. In this article, a literature analysis of the issue was conducted prior to the research process, which included theories of post-2007 crises, including the COVID-19 pandemic. The focus is on the theoretical background and research showing the impact of crises from the point of view of social, economic, and ecological dimensions, i.e., from the point of view of sustainable development. It also presents planned and implemented public intervention to offset the negative effects of COVID-19 in 2020 from structural funds in EU countries, including Poland and its 16 voivodeships.
\end{abstract}

Keywords: economic crisis; global pandemic; EU funds

\section{Introduction}

The world and Europe have been hit by crises throughout the 20th century. Every crisis is reflected in the economy [1,2]. Its emergence requires the implementation of measures that relate to enterprises as well as other spheres of the state, including social aspects. In the first half of the previous century, it was mainly the market that regulated economic crises [3]. Over the years, there has been a noticeable increase in public intervention by states in such situations. EU countries are increasingly shaping their economies as social. This process has been facilitated for decades by the increasing amounts allocated in the EU budget for the Cohesion Policy, that is, the EU Structural Funds [4]. They are planned and disbursed at the central level of individual countries as well as regionally. The regional approach takes place in Poland, which has 16 self-governing voivodeships. The COVID-19 pandemic has left its mark on the world economy [5] and took on the infamous name of global economic and social crisis. The COVID-19 pandemic provides clear evidence that 
human and planetary health are intimately linked [6], and the role of interdisciplinary approaches in finding solutions has been clearly highlighted [7].

With this in mind, to introduce the research, the article presents theories of the post2007 crisis and the effects of the COVID-19 pandemic. The focus is, therefore, on the theoretical background and research showing the impact of crises from the point of view of social, economic, and ecological dimensions. A statistical analysis of the support in 2020 from EU funds of Member States, including Poland and its 16 provinces, is subsequently illustrated in this article. Taking into account the funds at the disposal of the various Operational Programmes from the EU Financial Perspective 2014-2020, approval was obtained from the European Commission to transfer these funds to the fight against the COVID-19 pandemic. An analysis was made of the areas of support and amounts in each of the 16 Polish voivodeships from the available EU funds from the 2014-2020 financial perspective. The Opole Voivodeship was then analysed as a case study, i.e., the forms of support for health care from the funds of the Regional Operational Programme for the Opolskie Voivodeship 2014-2020 (ROP WO). It was assumed that public funds in health care were transferred to hospitals and health care units.

The aim of the conducted research is to analyse the amounts transferred in individual EU Member States for the fight against COVID-19, the amount of funds transferred in individual 16 Polish voivodeships from EU funds, including the most important areas of support, as well as to analyse the support for healthcare from the funds of the Regional Operational Programme for the Opolskie Voivodeship 2014-2020 (ROP WO). For the indicated research purposes, the following hypotheses are presented in the article. They have been verified as a result of the research. The limitation of the conducted research is that not all aspects of COVID are covered by it.

The following research hypotheses were formulated:

Hypothesis (H1). A Pareto distribution of cumulative support (20/80) can be observed in the values of support provided at European Union level.

Hypothesis (H2). Support within ROP programmes of particular regions of Poland was implemented from ERDF and ESF.

Hypothesis (H3). In the percentage breakdown of ROP support, ERDF is dominant compared to ESF.

Hypothesis (H4). Of the various areas of support to Poland to combat the effects of COVID-19, the most resources have been allocated to health care and entrepreneurship.

Hypothesis (H5). Negligible support was given to education, despite significant changes in the education system, i.e., remote education.

The conducted research and analyses based on it will allow us to indicate statistically the amount of EU funds allocated for the fight against COVID-19 in individual EU countries, the most important areas of support, during the pandemic, in individual 16 voivodeships from the available EU funds, relations between material aid received by hospitals and health care units, and spending of EU funds in the Opolskie Voivodeship.

\section{Analysis of the Issue-Literature Review Global Economic Crises}

Globally, the global economic crisis initiated in 2007 should be viewed through comparisons of what happened between 1900 and 2010 on the basis of certain indicators, including but not limited to banking, currency, debt (domestic and external), and inflation or stock market crashes and the impact on various areas of the economy, including the labour market [8]. This situation has certainly caused the socio-economic position of the European Union to deteriorate in terms of various macroeconomic variables [9] against a global [10] and demographic background [11]. 
This, in turn, forced the necessity to implement changes in programming and spending EU funds over time. Particular attention was paid to the need to evaluate their spending. This was directly related to the need to define those areas in the Union's development that will be important for the entire Community, as well as for individual member countries or regions [12]. The authors I. Iuga and A. Mihaliciuc in their works showed the dominant influence of certain macroeconomic indicators on economic growth [13]. The development of each country of the European Community is influenced by various external and internal factors. They must be continuously analysed in order to define the desired direction of development policy. Additionally, in order to eliminate the negative influences of unfavourable trends [14]. One of the concepts for developing and strengthening the competitiveness of the EU is sustainable development as enshrined in the Europe 2020 Strategy [15]. Sustainable development must be looked at very broadly. It affects many spheres, including sustainable production [16] or the assessment of progress in implementing the concept of sustainable development in the social aspects [17]. Širá et al. underline the importance of the knowledge-based economy. This factor is to be a driving force for increasing the competitiveness of countries' economies, and it contributes to their sustainable development [18]. Sustainable development also depends on the impact of the taxation system [19], actions for the environment and climate protection [20], ways of managing the life cycle of products, using artificial intelligence in enterprises [21,22], integrated urban technologies, sustainable energy system, or in general intelligent energy management $[23,24]$. Poland was also one of the countries affected by the economic crisis [25]. Being an integral part of the world economic system, it is also influenced by the world economy [26-28]. The development of its individual regions and their growth potential has been stimulated by the support of the European Union structural funds [29]. EU actions had a significant impact on mitigating the effects of the global crisis, due to their goals. In the years 2007-2013 and 2014-2020, Poland was the largest recipient of EU support among all EU countries. In the period 2007-2013, it was EUR 80.58 billion (18.19\%) of the total budget of the EUR 442.96 billion. For the period 2014-2020 it is over EUR 87 billion (18.37\%) of the EUR 474.31 billion of support granted to all Member States [30]. In Poland, GDP per capita in 2004 was 51\% of the EU average; in 2019, it was 73\%, and in over 15 years, it has increased by $22 \%$ [31].

A crisis may have many faces. The Director General of the World Health Organization (WHO) admitted that COVID-19 should be characterized as a pandemic and that it is precisely a crisis. It affects not only public health, but every sector of the economy. Analysts around the world are speculating whether this situation will accelerate existing trends or turn out to be a geopolitical breakthrough, creating a completely different world than before. The answer is more complicated, and the world during and after COVID-19 will contain elements both old and new, known and unknown. It is important to consider both the geopolitical context of the pandemic and the new space it opens up [32]. Experience has shown that the pandemic leaves its mark on the European economy, for which development prospects are not optimistic. Emerging new COVID-19 variants have forced Member States to be constantly prepared to introduce various preventive measures, often of a very stringent nature.

However, there is light at the end of the tunnel, where the European economy has been for almost a year. The vaccination campaign is underway, and the restrictions are gradually being eased. It is also expected that the activity of economies, individual sectors as well as private consumption will increase, with additional support from world trade [33]. The example of Central and Eastern European countries shows a month-on-month decrease in quantitative and qualitative variables describing the economic situation, based on the reactions of economic agents adapting to the situation [34]. Analysing Poland's main economic indicators, one can see the visible impact of the pandemic on their level [35].

A. Sapir analyses selected countries in Europe to try to find the reasons why some countries' economies have suffered more from COVID-19 than others. There are several reasons for this situation, including the number of deaths per million people, the severity 
of the restrictions applied, the structure of the economy, and the government's ability to counteract the collapse of economic activity. However, so far, no systematic attempt has been made to divide responsibilities between various potential factors. Understanding why some countries have suffered more than others could help to plan how countries should be helped under the Recovery and Resilience Facility (RRF), the main instrument of the new fund $[36,37]$. R. Arbolino and P. Di Caro reflect on the flexibility of regional EU funds during a pandemic from the point of view of, inter alia, labour market [38].

The COVID-19 pandemic has also had an unprecedented impact on the environment [39]. Moreover, the pace of activity has slowed down in all urban agglomerations with over a million inhabitants in Europe, and traffic and economic exchanges have practically stalled. Actions by governments, both locally and regionally, have resulted in both negative and positive effects, ranging from the immediate to long term. A full impact assessment is far from possible due to an ongoing catastrophe of epic proportions and immense complexity [40].

Cohesion Policy support from the EU budget amounted to over EUR 463 billion in 2014-2020 [41]. These funds support the socio-economic development of individual member states based on the objectives of the Europe 2020 strategy. At the moment, funds that have not yet been contracted are being used to strengthen European economies during the global crisis. The forms of support are presented in the analysis and research part of the article.

The European Union has earmarked over EUR 750 billion until 2026 to rebuild the European economy after the COVID-19 pandemic. In addition, countries have more than EUR 1 trillion at their disposal under the Multiannual Financial Framework, the EU's seven-year budget. These funds must be spent by 2029 [42]. Table 1 presents measures for 27 Member States, including Poland.

Table 1. Breakdown of EU allocation to Poland for 2021-2027.

\begin{tabular}{lc}
\hline \multicolumn{1}{c}{ EU Budget } & Allocation 2021-2027 (Billion EUR) \\
\hline Multiannual Financial Framework (7-year EU budget): & 1074.3 \\
Including COHESION POLICY 2021-2027 & 330.2 \\
Poland & 71.0 \\
EU recovery instrument: & 750.0 \\
Poland & 58.1 \\
TOTAL POLAND & 129.1 \\
\hline
\end{tabular}

\section{Research Methodology}

Implementation Algorithm

While identifying and analysing Structural Fund support for the effects of the COVID19pandemic, the evolution of the value of support for EU countries was examined first. These values are expressed in total and cumulative values. Then, the values of support for Poland and its 16 voivodeships were presented. This support is described in total with simultaneous inclusion of ERDF and ESF programmes.

In the next stage of the conducted research, support for four selected dimensions, namely, health and society, education, entrepreneurship, and wage subsidies, was described in detail. Due to the significant support in the category of health and society in the last stage of the research, an analysis was carried out on the basis of a case study of the support provided in the Opolskie Voivodeship for health care units. The described stages of the research are presented in Figure 1. The statistical analysis tools used in the final stage of the study were correlation and regression analysis. 


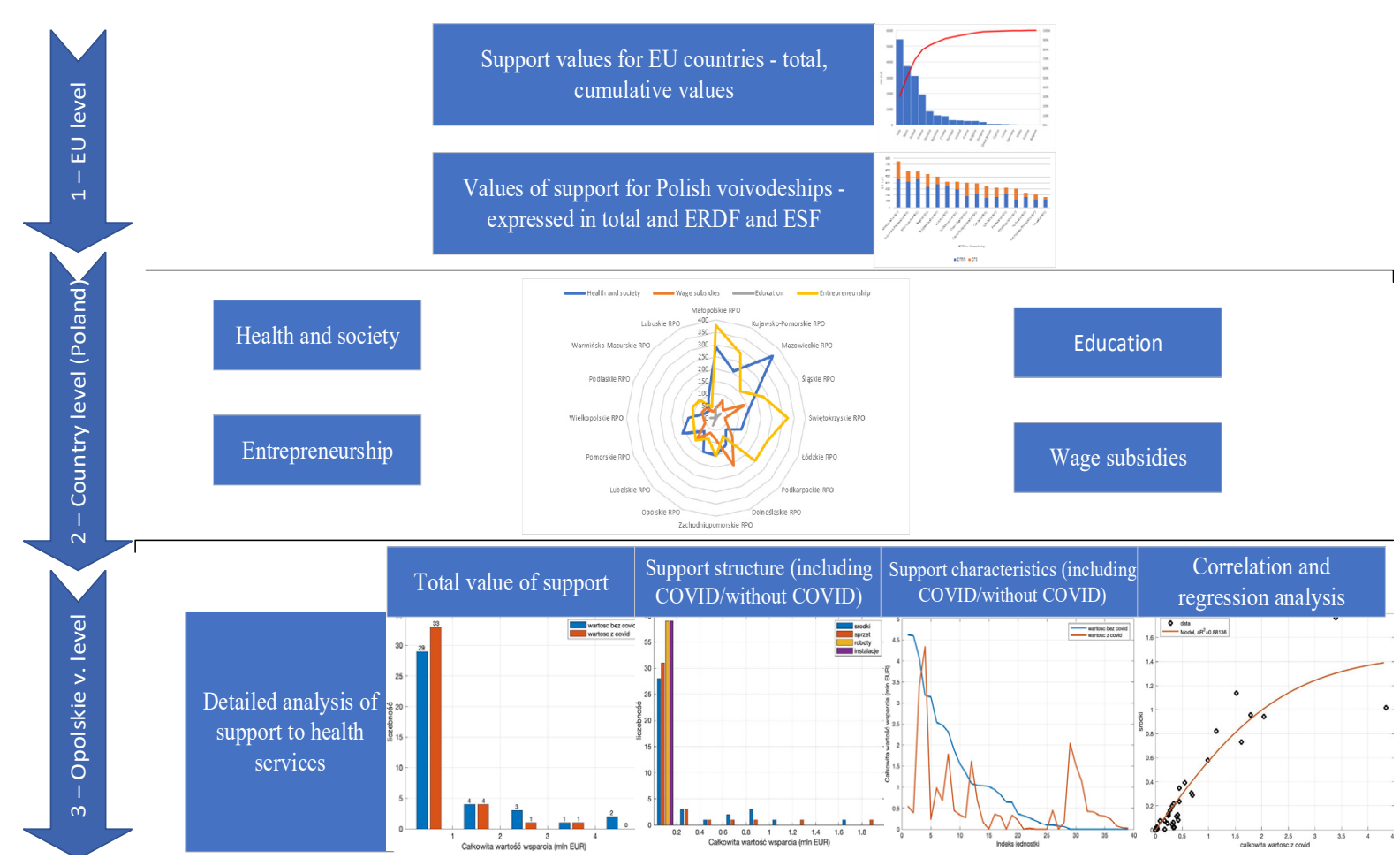

Figure 1. Stages of research implementation.

4. Identification and Analysis of Structural Fund Support Mitigating the Effects of the COVID-19 Pandemic

A Case Study for Europe and Poland

Taking into account the defined stages of the research, the analytical and research part of the study primarily presents:

- Support values for individual EU countries, including cumulative values;

- The value of support for individual 16 voivodeships of Poland, including a breakdown into support under the ERDF and ESF;

- Types and values of support for 16 voivodeships in Poland, including in detail support for health and society, education, entrepreneurship, and wage subsidies;

- Analysed in detail the support for hospitals and health care units on the example of the Opolskie Voivodeship.

It should be noted that the analyses made use of data obtained from the Marshal's Office of the Opolskie Voivodeship, which were obtained on the basis of access to public information and the websites of the European Commission. Values presented in the acquired data refer to the above defined analysis areas and are acquired as of 21 April 2021.

Turning to the analysis of the first examined area, i.e., the value of support per EU country, it can be seen that three countries have provided very large values within the available operational programmes from 2014-2020. Italy, Spain, and Poland contributed EUR 5.4 billion, EUR 3.7 billion, and EUR 3.1 billion, respectively. In order to demonstrate the significant share of support for these three countries, the cumulative support values are also shown in the described graph. From these values, it can be concluded that the countries described, i.e., Italy, Spain, and Poland, contributed approximately $80 \%$ of the funds allocated to all Member States. It should also be noted that the values of support are in no way correlated with the size of a given country, since for the UK and Germany, which are relatively large countries, the support obtained is very low (Figure 2).

At this point of the research, it should also be noted that in view of the values of support, detailed research should be conducted for those countries for which the support was relatively large and for those for which it is possible to obtain reliable data at the level of the country and its regions (voivodships). Considering the abovementioned assumption, 
Poland was selected for further analysis, and the Opolskie Voivodeship was analysed in detail as the leader in effective use of ROP funds among 16 Polish regions.

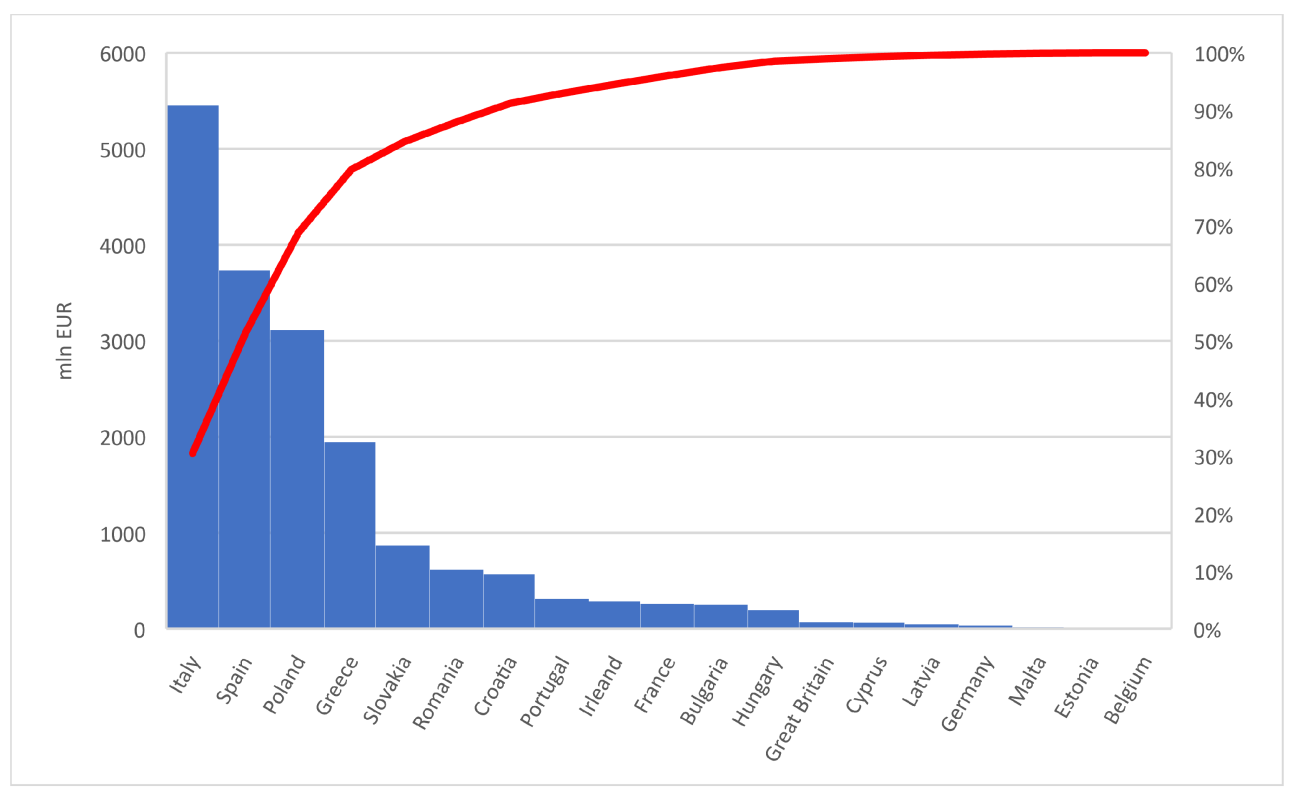

Figure 2. Total and cumulative value of support provided in EUR to combat the effects of pandemic COVID-19.

The first step in detailing the research is to present the disbursement of funds for the COVID-19 pandemic by European Regional Development Fund (ERDF) and European Social Fund (ESF) - cf. Figure 3. In the presented graph, we can see that the highest support for the fight against the COVID-19 pandemic was received by the Małopolskie Voivodeship, followed by the Kujawsko-Pomorskie Voivodeship and the Mazowieckie Voivodeship. The least support was received by the Lubuskie, Warmińsko-Mazurskie, and Podlaskie Voivodeships. It can also be seen from the graph that in most of the voivodeships, the scope of support under the ERDF is greater than under the ESF, with the exception of Dolnoślaskie, Opolskie, and Wielkopolskie Voivodeships.

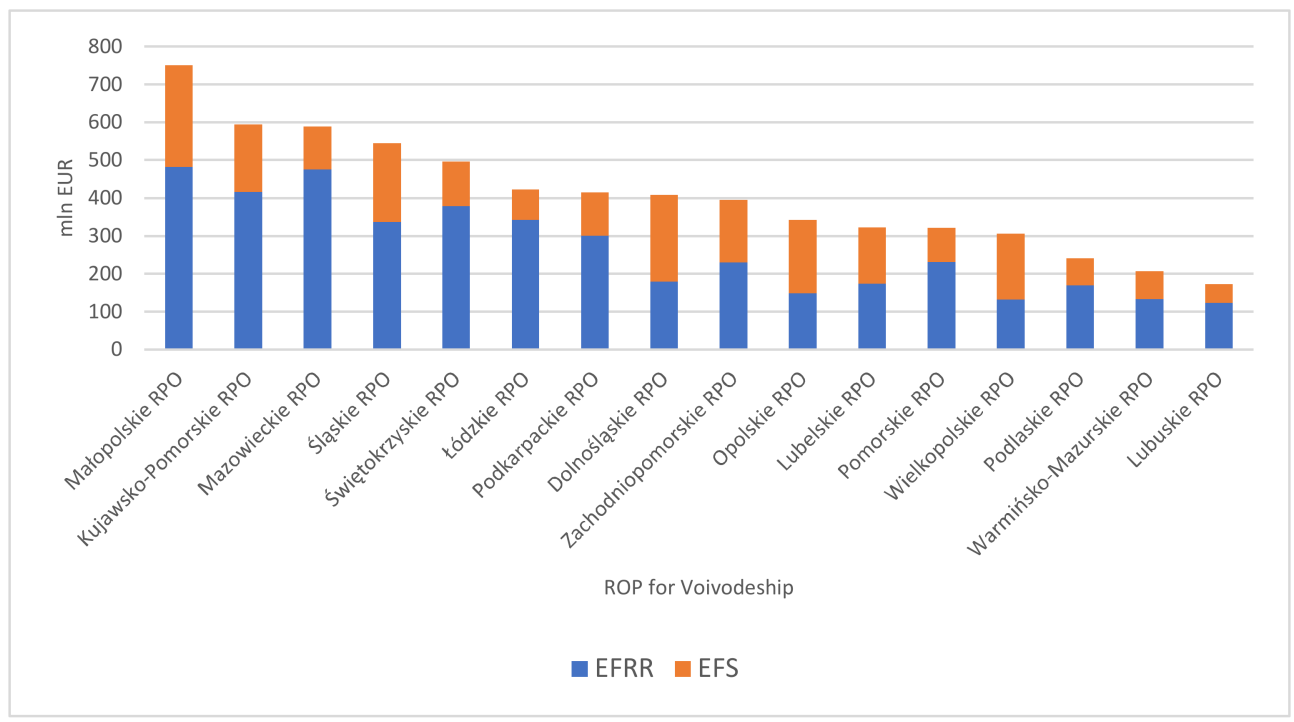

Figure 3. Breakdown of COVID-19 expenditure by European Regional Development Fund (ERDF) and European Social Fund (ESF). 
The Opolskie Voivodeship received EUR 148,146,156 under ERDF support and EUR $193,751,584$ from the ESF. Figure 4 presents the structure of support for individual voivodeships, broken down into support for health and society, education, entrepreneurship, and subsidies to employees' salaries.

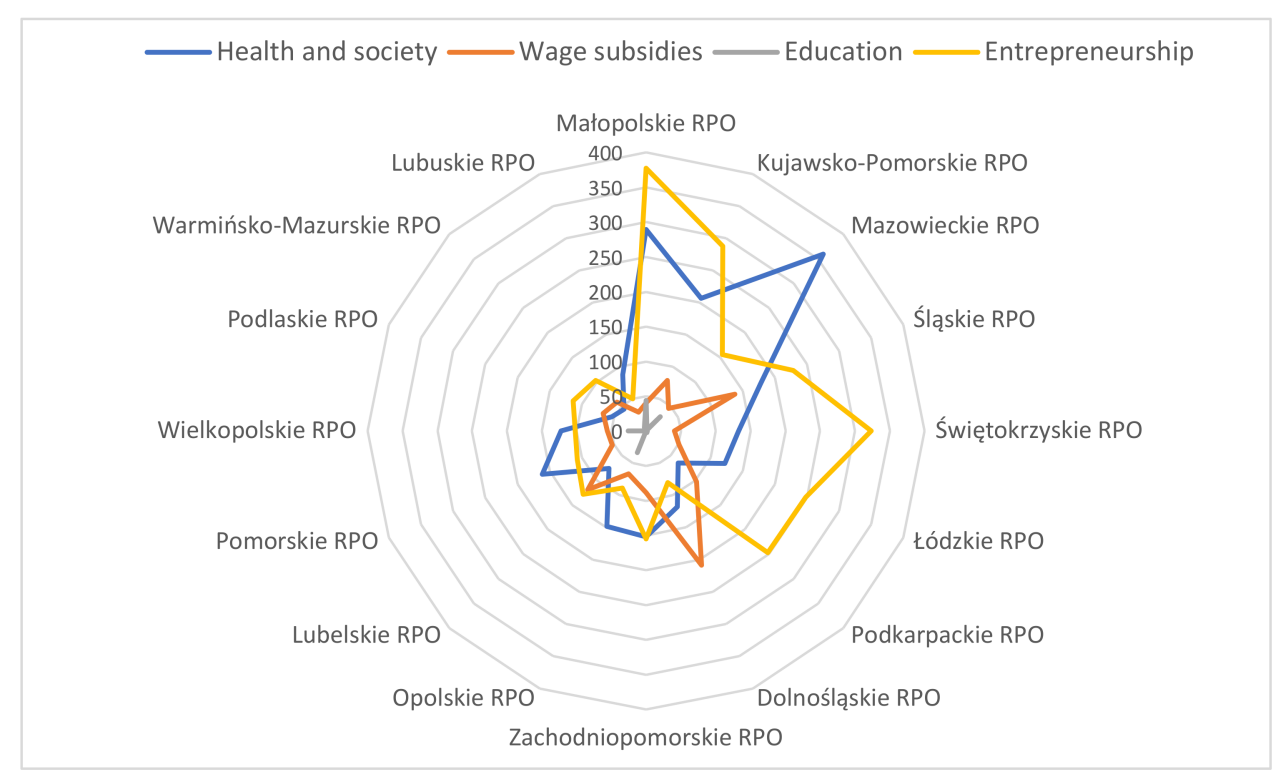

Figure 4. Structure of support for individual voivodeships, with a breakdown into support for health and society, education, entrepreneurship, and subsidies to employees' salaries (mln EUR).

From the presented graph, it can be concluded that entrepreneurship and health services are the two areas that received the highest values of support due to the COVID-19 pandemic. From the point of view of economic logic, the significant values of support for entrepreneurship and health care are justified: entrepreneurship since the vast majority of industries were closed down by COVID-19, and health services since a large proportion of the population became ill or died because of the pandemic. From the presented graph, we can also see that very little resources have been allocated to education to support the COVID-19 fight.

Significant support for entrepreneurship was received by the Małopolskie Voivodeship (EUR 377 million), Świętokrzyskie Voivodeship (EUR 323 million), and Podkarpackie Voivodeship (EUR 247 million). On the other hand, for health and society, the Mazowieckie Voivodeship (EUR 359 million) and Małopolskie Voivodeship (EUR 289 million) significantly differ in the value of received support.

\section{Detailed Analysis of Structural Fund Support for the Effects of the Pandemic A Case Study for the Opolskie Voivodeship}

Figure 5 presents the value of support given to hospitals and health care units under the Regional Operational Programme of the Opolskie Voivodeship. The presentation of the provided support is shown for its two types. Firstly, systemic (basic) support within PRO WO and additional support received by the described units as a result of the situation related to the COVID pandemic. From the presented graph, we can see that the range of support granted in the Opolskie Voivodeship varied from relatively low amounts to EUR 5 million. It should also be noted that hospitals and health care units up to EUR 1 million were supported in the widest extent. It can also be seen from Figure 5 that none of the entities surveyed received more than EUR 4 million in support for COVID pandemic mitigation. 


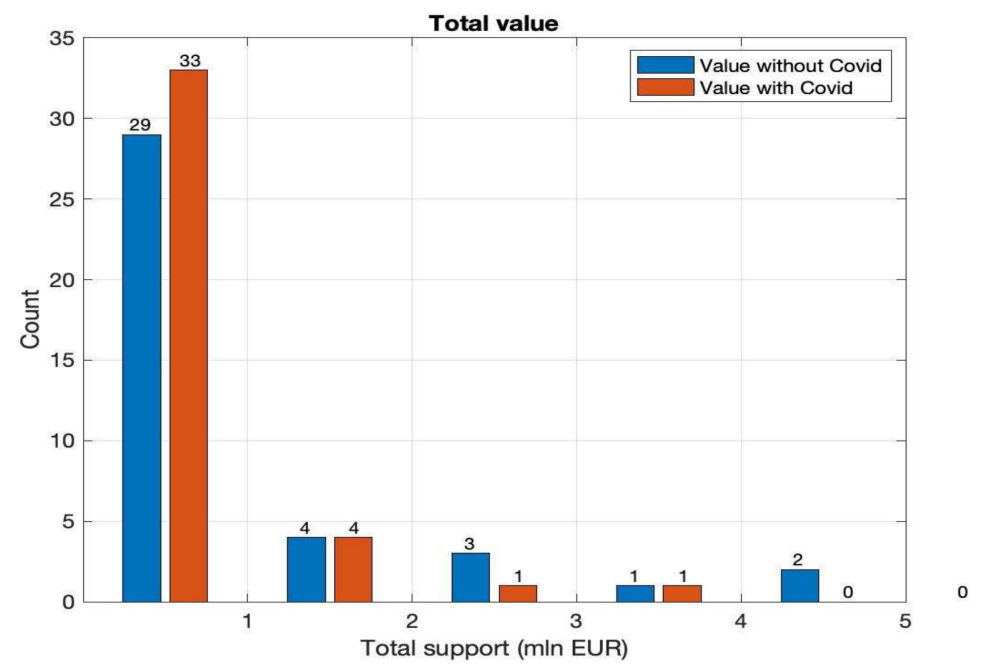

Figure 5. Support for hospitals and health care units under Regional Operational Programme for the Opolskie Voivodeship RPO WO 2014-2020.

In the next stage of the research, an attempt was made to analyse the structure of the support received by the described units within the framework of activities related to the COVID pandemic. This analysis was carried out for two ranges of support, i.e., for support up to EUR 2 million and for support up to EUR 0.5 million. The described distributions of the granted support by their structure are presented in Figures 6 and 7, respectively. From the charts, it can be seen that the additional funding under the COVID countermeasures relates to:

- Personal protective equipment;

- Equipment;

- Construction works;

- Oxygen installations, walls.

From Figures 6 and 7, it can be seen that the largest amount of funding that has taken place is up to EUR 100,000. It can also be noted that most of the surveyed entities received financial support for the construction of oxygen installations and walls and for construction works. The described funding structure seems logical, as it represents all adaptation activities, hospitals, and health units, preparing them to fight the COVID pandemic.

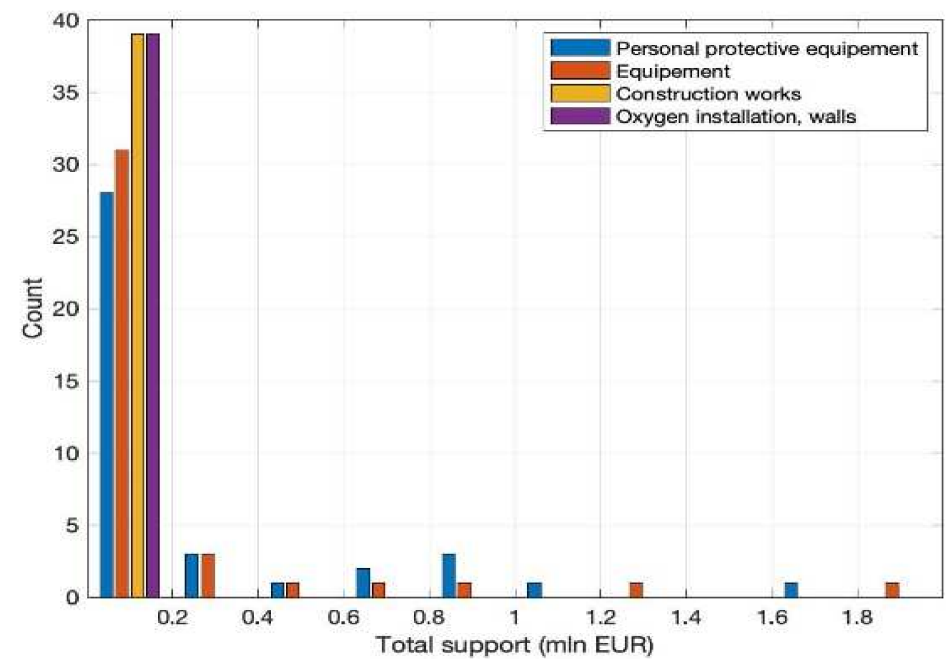

Figure 6. Support structure for COVID pandemic mitigation (values up to EUR 2 million). 


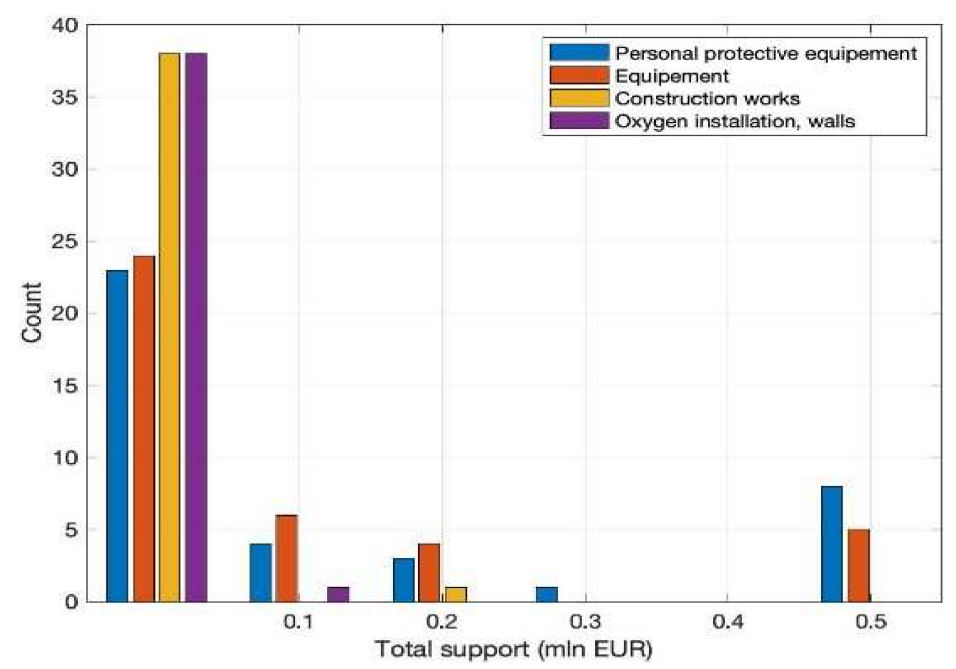

Figure 7. Support structure for COVID pandemic mitigation (values up to EUR 0.5 million).

In the next step of the study, a comparative analysis of the payments made before and after the outbreak of the COVID pandemic was carried out. This analysis was intended to show what relationships occurred in the payments. In Figure 8, it can be seen that those hospitals and health units that did not receive funding before the COVID pandemic did receive funding after the outbreak. In Figure 8, the described example takes place for units with a sequence number above 30. It can also be seen from Figure 8 that there is no correlation between the amount of resources obtained before the pandemic and those obtained after the outbreak. In order to carry out a more detailed analysis of the issue under study, Figures 9 and 10 have been drawn up to show the characterisation of support according to the form of ownership, i.e., divided into private and public units, respectively.

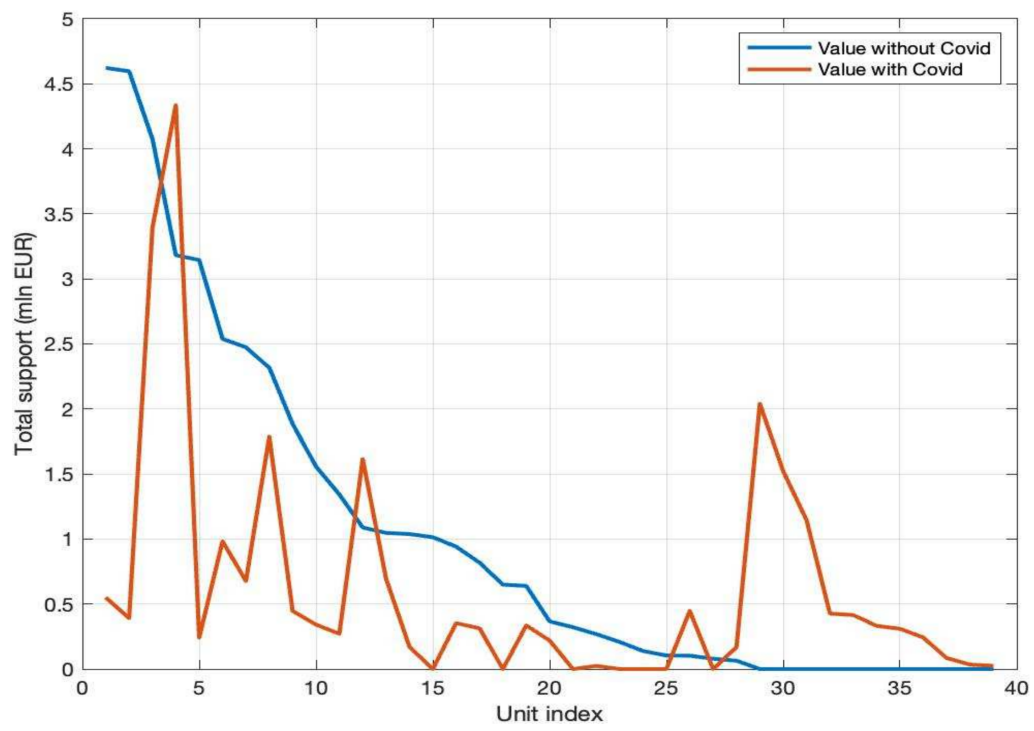

Figure 8. Characteristics of support (COVID division, without COVID). 


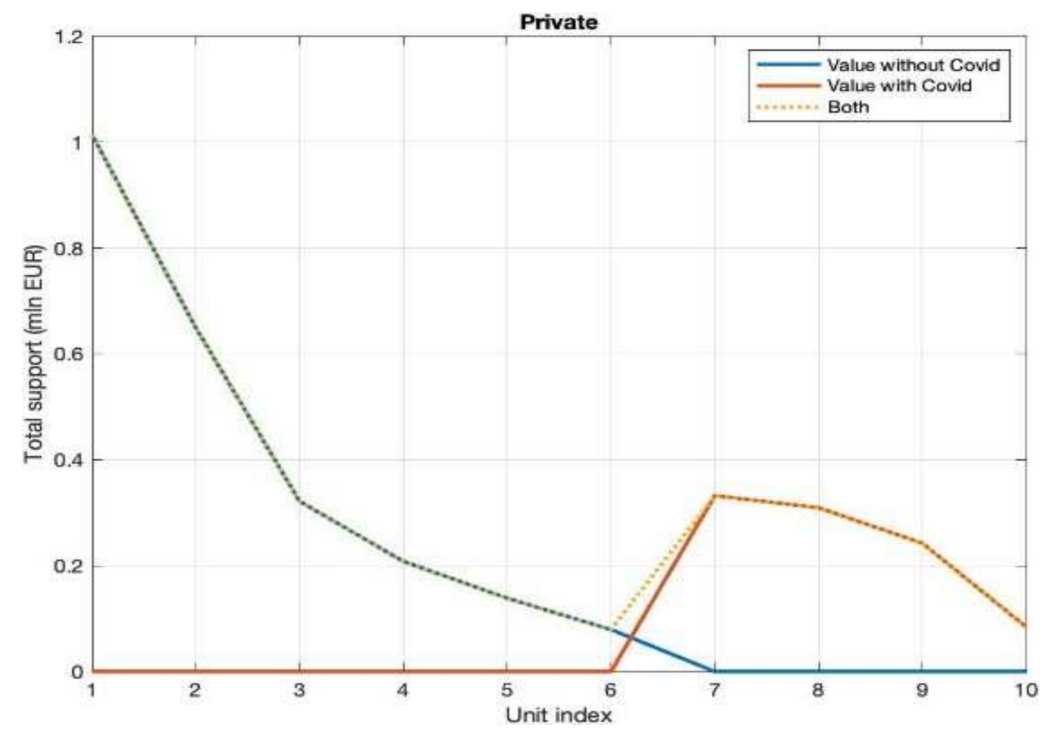

Figure 9. Support characteristics-private sector (COVID division, without COVID).

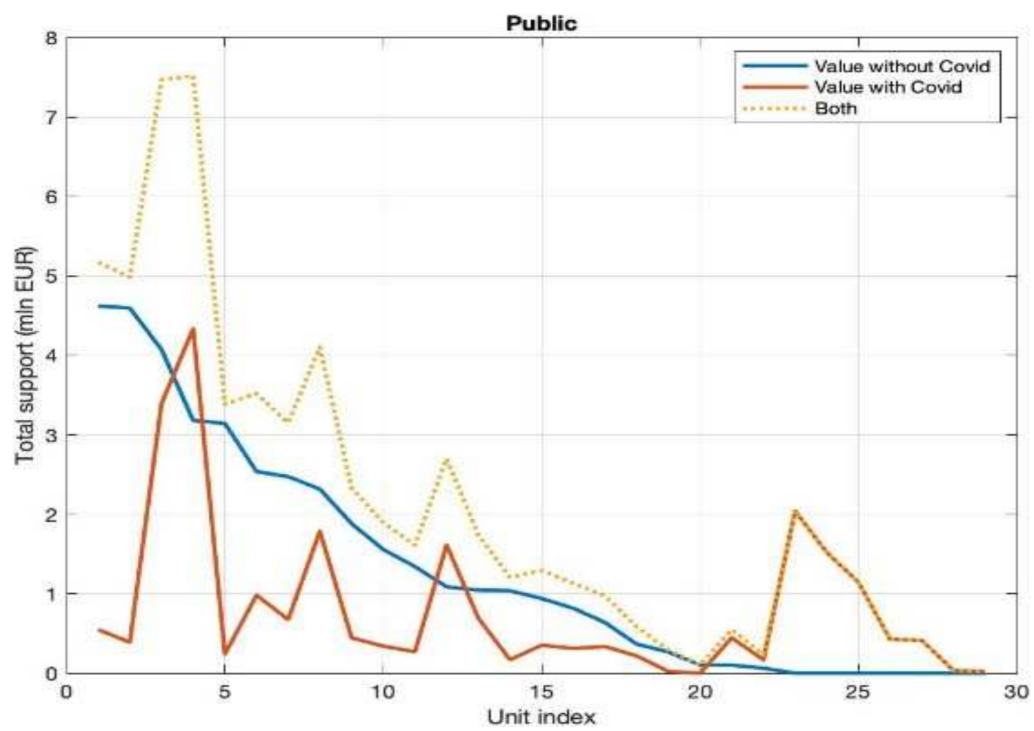

Figure 10. Support characteristics-public sector (COVID division, without COVID).

An interesting situation in the structure of obtained subsidies takes place in units belonging to the private sector. It can be seen from Figure 8 that alternate funding can be observed in this sector, i.e., those units that received funding before the emergence of the COVID pandemic after its emergence did not receive additional funding. However, units that did not receive funding before the COVID pandemic after its outbreak obtained such funding. On the other hand, when describing the characteristics of subsidies for the public sector, it can be said that it follows the same pattern as for total data, i.e., aggregated data.

The final stage of the study was to test the functional correlation relationship that exists between the total value of grants provided during the COVID pandemic and the values of payments allocated to equipment (Figure 11), personal protective equipment (Figure 12), oxygen installations and walls (Figure 13), and constructions works (Figure 14), respectively. 


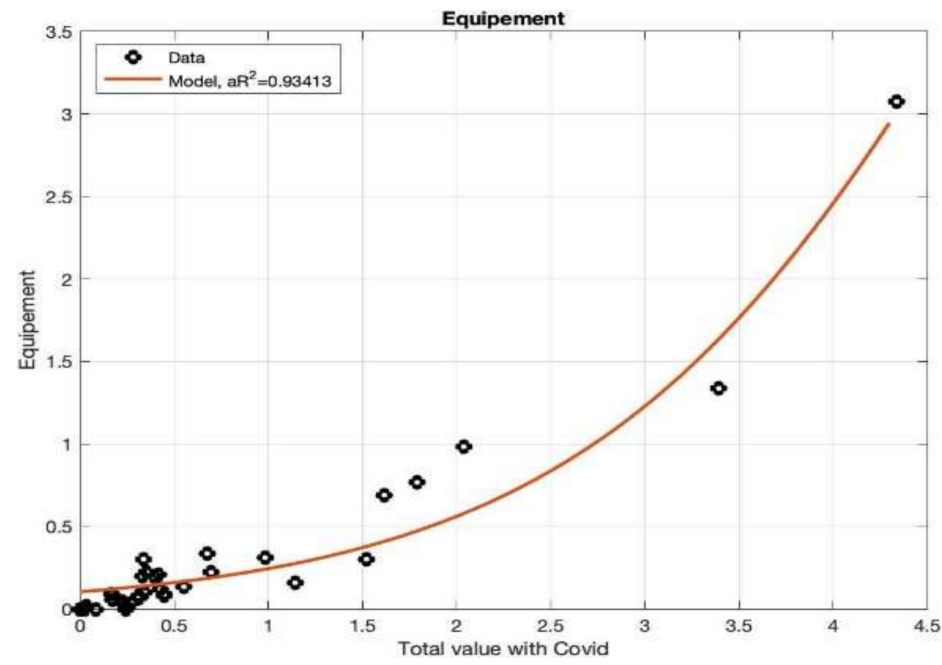

Figure 11. Correlation relationship of total COVID funding vs. equipment.

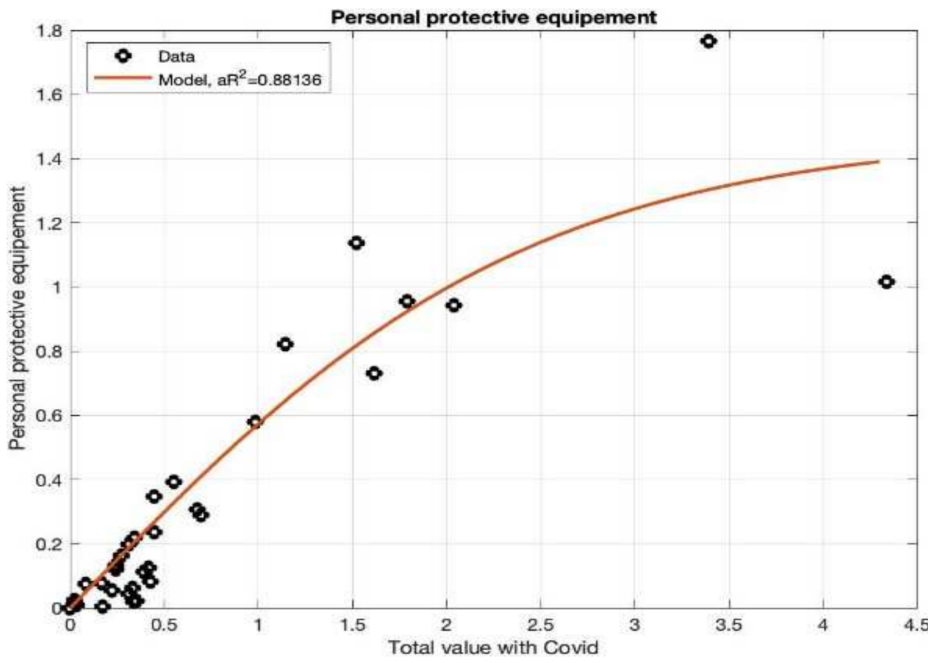

Figure 12. Correlation relationship of total COVID funding vs. personal protective equipment.

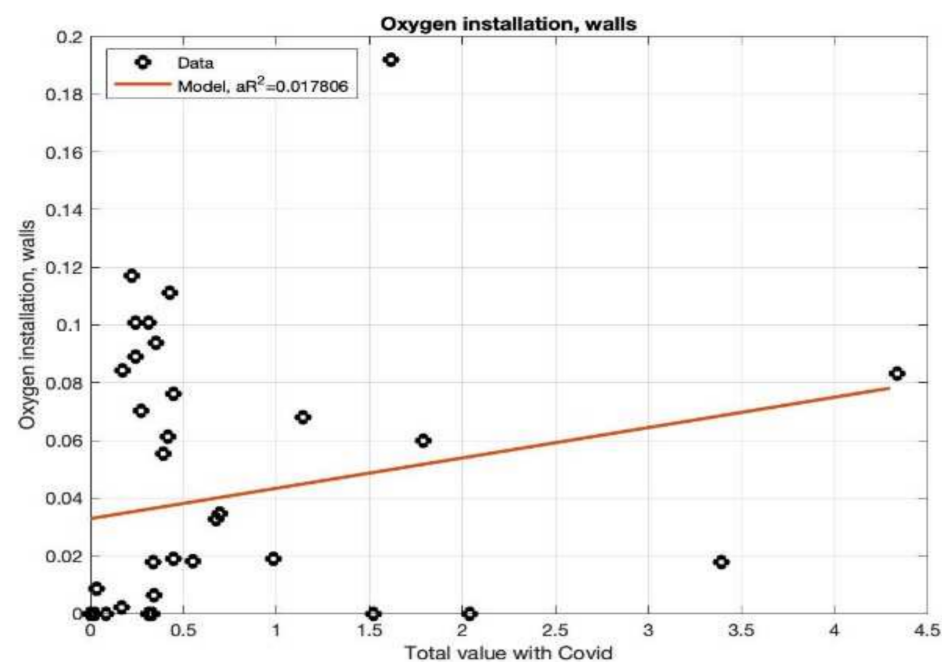

Figure 13. Correlation relationship of total COVID funding vs. installations (oxygen, walls). 


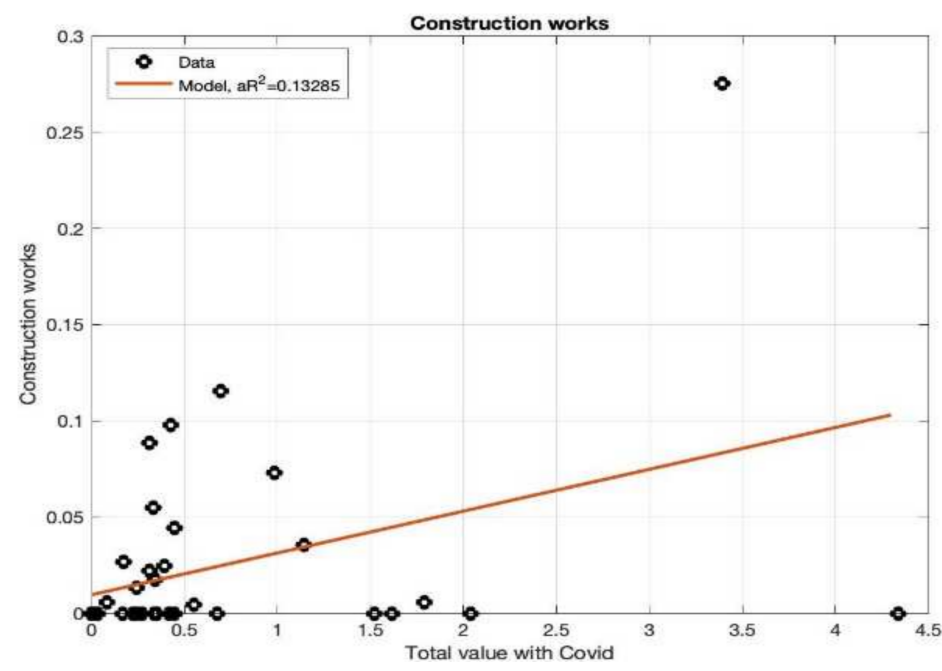

Figure 14. Correlation relationship of total COVID funding vs. construction works.

From Figure 11, it can be concluded that the functional dependence of the presented scatter plot has the character of an exponential function. It can, therefore, be concluded that in the case of subsidies obtained for equipment, the greater the amount of total subsidy, the amount subsidised for equipment increases exponentially. In the case of subsidies for personal protective equipment, the functional dependence that was observed was that of decreasing increments (Figure 12). It can, therefore, be hypothesised that as the total funding for COVID activities increases, the funding for measures is relatively reduced. From Figures 13 and 14, it can be seen that for oxygen installations and construction works, there is no correlation between the expenditure allocated to them and the value of the obtained subsidy.

\section{Conclusions}

The carried out research allowed for a description of the provided financial support, in individual EU Member States, for the effects of the COVID-19 pandemic under the ongoing operational programmes from the EU 2014-2020 perspective. The identification of the most important areas of support and the amounts allocated to them for Poland and its sixteen voivodeships under the available EU funds from the perspective 2014-2020 was carried out. Types and forms of support for health services from the funds of the Regional Operational Programme for the Opolskie Voivodeship 2014-2020 (ROP WO) were analysed in detail, treating the Opole Voivodeship as a case study.

In order to obtain the most systematic research inference possible, a literature analysis of the issue was carried out as a first step. The analysis shows the role of global crises over the years, including the COVID-19 pandemic and the increasing role of public intervention. This has been very evident in the EU Member States over recent years, and the situation over the last year has made this clear, with funds from the 2014-2020 perspective being allocated to the fight against the pandemic as well as more than EUR 750 billion allocated by the European Commission to rebuild the European economy.

Taking into account the utilitarian dimension of the carried out analyses, it can be noted that the three countries have provided highly significant values for the fight against the effects of COVID-19, within the available operational programmes between 2014 and 2020. These are Italy, Spain, and Poland who contributed EUR 5.4 billion, EUR 3.7 billion, and EUR 3.1 billion, respectively. When analysing the cumulative values of support, described countries have provided around $80 \%$ of the funds allocated to all Member States. Further research should be conducted for those countries for which this support was relatively large and for those for which it is possible to obtain reliable data at the level of the country and its regions (voivodships). 
On the other hand, the most important research results at the level of Poland and its voivodships, in particular of the Opolskie Voivodeship, are presented below:

- In the majority of voivodeships, the scope of support under the ERDF is greater than under the ESF, with the exception of three voivodeships from 16.

- In Poland, from the structural funds at the disposal of the authorities of 16 voivodeships, entrepreneurship and health services are the two areas that received the largest amounts of support due to the COVID-19 pandemic. From the point of view of economic logic, the significant values of support for entrepreneurship and health care are justified: entrepreneurship since the vast majority of industries were closed down by COVID-19, and health services since a large proportion of the population became ill or died because of the pandemic.

- In the Opolskie voivodeship case study, the additional financing in the health area under the COVID countermeasures concerns: personal protective equipment, equipment, civil works, oxygen installations, and waste water management. The most common funding that has taken place is up to EUR 100,000. In the private health sector, alternate funding can be observed, i.e., those units that received funding before the emergence of the COVID pandemic did not receive additional funding after its emergence. However, units that did not receive funding before the COVID pandemic after its outbreak obtained such funding. On the other hand, when describing the characteristics of subsidies for the public sector, it can be said that it follows the same pattern as for total data, i.e., aggregated data.

It is not easy to assess the impact of structural funds on the economies of EU Member States in times of crisis. It is often difficult to determine to what extent public aid directly reduces the effects of the crisis, and thus, whether it has an impact on the socio-economic development of a country or a region. The authors of this study are aware that they only show a model approach to the problem. Of course, it shows a simplified picture of reality. They only show correlation and regression relations, without explaining cause-effect relations, taking into account the place in the economy.

The carried out analyses showed that there was a positive response by the public authorities to the 2020 crisis, with funds from available programmes being allocated to the fight against the pandemic. The obtained research results may have a practical impact on the decisions of authorities at various levels (regions, countries, the entire Community) responsible for spending EU funds.

The authors point out the following recommendations to authorities of all levels regarding EU spending:

- The rules of implementing operational programs from structural funds should be subject to constant discussion and verification. These activities are of a permanent nature. They are intended to be a bridge between European, national, and regional authorities and program stakeholders. This approach guarantees greater awareness, flexibility, and efficiency in terms of the role of public funds and the speed of their spending.

- Participants of EU-funded project initiatives should participate in awareness-raising information and education campaigns promoting the role and importance of Structural Funds in past, present, and future economic crises.

- It is of fundamental importance to raise awareness of this approach from the point of view of macroeconomic indicators important for the development of the EU economy and its individual countries, including creating new employment, wage levels, or the pace of housing building.

- The COVID-19 pandemic has clearly shown that evaluations of the spending of EU funds (payments from the operational program) are the basis for making decisions in times of crisis. This area should be constantly supervised by authorities responsible for European funds at all levels, in order to quickly implement remedial actions. It is important that repair models make use of past experience. 
- The limitation in the research conducted by the authors is that not all possible aspects of support with EU public funds were taken into account in the research process.

- EU public funds are an important element in supporting the economies of the 27 European Union countries in times of crisis.

Thus, the economic and social position of the European Union on the world stage is the result of joint and coordinated actions of the European, national, and regional authorities of individual Member States, but also the effect of the 2007 crisis. Additionally, this position is now visible through the effects of the pandemic, as noted in the article. For example, for Poland, which is a member of the EU, this is of particular importance. The country is the largest recipient of EU funds for 2014-2020 and 2021-2027. EU funds are the main tool of project initiatives here. Moreover, their use positively influences the macroeconomic indicators of the country. At the same time, they have been used extensively in the fight against the pandemic in 2020.

Member States face the enormous challenge of spending more than EUR 750 billion from the European Recovery Facility to deal with the effects of the pandemic. The pandemic has created and will probably continue to create new barriers. However, they should be effectively minimized, and the spending of EU funds will revive the European economy.

Author Contributions: Conceptualization, K.B., Ł.M., A.K. and A.B.; Formal analysis, Ł.M.; Investigation, K.B. and A.B.; Methodology, Ł.M.; Project administration, A.K.; Resources, K.B.; Writingoriginal draft, K.B., A.K. and A.B.; Writing-review \& editing, Ł.M. All authors have read and agreed to the published version of the manuscript.

Funding: The APC was funded by Opole University of Technology.

Acknowledgments: The paper presents the personal opinions of the authors and does not necessarily reflect the official position of Marshal Office of Opolskie Voivodship.

Conflicts of Interest: The authors declare no conflict of interest.

\section{References}

1. Kundera, E. Ład Ekonomiczny po Wielkim Kryzysie Gospodarczym w Koncepcji Stanisława Grabskiego; Wydawnictwo Uniwersytetu w Białymstoku: Bialystok, Poland, 2015.

2. Bochenek, A. Rozważania historyczno-semantyczne na temat kryzysów ekonomicznych. Acta Univ. Nicolai Copernici. Ekonomia 2012, 43, 147-159. [CrossRef]

3. Dudziński, J. Kryzys surowcowy, paliwowy i żywnościowy lat 70. XX wieku a boom surowcowy XXI wieku—Podobieństwa i różnice. Zesz. Nauk. Uniw. Szczecinskiego Stud. Pr. Wydz. Nauk Ekon. Zarzadzania 2013, 33, 19-32.

4. Ryszkiewicz, A. Wybrane instrumenty polityki gospodarczej Unii Europejskiej w zakresie przezwyciężenia skutków kryzysu gospodarczego. Zesz. Nauk. Szk. Glowna Handlowa Kol. Gospod. Swiatowej 2012, 34, 5-29.

5. Mikulewicz, M. Z badań nad rozowjem Polski na tle pzremian w Europie i na świecie. Koncepcje teoretyczne i doświadczenia praktyczne. Przeglad Ekon. 2020, 20, 100.

6. COVID-19 and Air Pollution: A Deadly Connection. Available online: https:/www.weforum.org/agenda/2020/04/the-deadlylink-between-covid-19-and-air-pollution/ (accessed on 11 May 2020.).

7. Sun, J.; He, W.-T.; Wang, L.; Lai, A.; Ji, X.; Zhai, X.; Li, G.; Suchard, M.A.; Tian, J.; Zhou, J. COVID-19: Epidemiology, evolution, and corss-disciplinary perspectives. Trends Mol. Med. 2020, 26, 483-495. [CrossRef] [PubMed]

8. Reinhart, C. A Series of Unfortunate Events: Common Sequencing Patterns in Financial Crises. NBER 2012. [CrossRef]

9. Van den Noord, P. Economic Crisis in Europe: Causes, Consequences and Responses; European Economy: Luxembourg, 2009.

10. Radulescu, M.; Fedajev, A.; Sinisi, C.I.; Popescu, C.; Iacob, S.E. Europe 2020 Implementation as Driver of Economic Performance and Competitiveness. Panel Analysis of CEE Countries. Sustainability 2018, 10, 566. [CrossRef]

11. Ogólski, M. Wyzwania Demograficzne Europy i Polski. In Europejskie Wyzwania dla Polski i jej Regionów; Ministerstwo Rozwoju Regionalnego: Warsaw, Poland, 2010.

12. Bedrunka, K.; Malik, K. Zintegrowana efektywność polityki rozwoju regionalnego w okresie programowania 2014-2020. Handel Wewnętrzny 2012, 2, 7-18.

13. Iuga, I.; Mihaliciuc, A. Major Crises of the XXIst Century and Impact on Economic Growth. Sustainability 2020, 12, 9373. [CrossRef]

14. Klasik, A. Przedsiębiorczość i Konkurencyjność a Rozwój Regionalny-Wprowadzenie. In Przedsiębiorczość i Konkurencyjność a Rozwój Regionalny; Klasik, A., Ed.; Akademia Ekonomiczna im. Karola Adamieckiego w Katowicach: Katowice, Poland, 2006; p. 598. ISBN 83-7246-938-5.

15. Europa 2020. Strategia na Rzecz Inteligentnego i Zrównoważonego Rozowju Sprzyjajacego Właczeniu Społecznemu; European Comission: Brussels, Belgium, 2010. 
16. Królczyk, G.; Król, A.; Kochan, O.; Su, J.; Kacprzyk, J. Sustainable Production: Novel Trends in Energy, Environmental and Materials Systems; Springer: Cham, Switzerland, 2020; ISBN 978-3-030-11273-8.

17. Barska, A.; Jedrzejczak-Gas, J.; Kononowicz, J.; Wyrwa, J.; Kononowicz, K. Multidimensional Assessment of the Social Development of EU Countries in the Context of Implementing the Concept of Sustainable Development. Sustainability 2020, $12,7821$. [CrossRef]

18. Širá, E.; Vavrek, R.; Vozárová, I.K.; Kotulič, R. Knowledge Economy Indicators and Their Impact on the Sustainable Competitiveness of the EU Countries. Sustainability 2020, 12, 4172. [CrossRef]

19. Ionescu, L. The economics of teh carbon Tax: Enviromental Performance, Sustainable Energy, and Geen Financial Behavior. Geopolit. Hist. Int. Relat. 2020, 12, 101-107.

20. Pflugman, F.; De Blasio, N. Geopolitics of Renewable Hydrogen in Low-Crbon Energy Markets. Geopolit. Hist. Int. Relat. 2020, 12, 9-44.

21. Tacker, G. Sustainable Product Lifecycle Managment, Industrial Big Data, and Inernet of Things Sensing Networks in CyberPhisical System-based Smart Factories. J. Self Gov. Manag. Econ. 2021, 9, 9-19.

22. Lazaroiu, G.; Klistik, T.; Novak, A. Internet of Things Smart Devices, Industrial Artificial Intelligenc, and Real-Time Sensor Neworks in Sustainable Cyber-Physical Production Systems. J. Self Gov. Manag. Econ. 2021, 9, 20-30.

23. Harrower, K. Networked and Integrated Urban Technologies in Sustainable Smart Energy Systems. Geopolit. Hist. Int. Relat. 2020, $12,45-51$.

24. Eysenck, G. Sensor-based Big Data Aplications and Computationally Networed Urbanism in Smart Energy Systems. Geopolit. Hist. Int. Relat. 2020, 12, 52-58.

25. Adamowicz, M.; Adamowicz, T. Przebieg i skutki światowego kryzysu finansowego lat 2007-2011 oraz działania antykryzysowe w Polsce. Pr. Nauk. Uniw. Ekon. Wroclawiu 2018, 529, 11-27. [CrossRef]

26. Mobarak, H.; Niaz, M. Antoine Augustin Cournot: The Pioneer of Modern Economoc Ideas; MPRA: Reno, NV, USA, 2018.

27. Kuczmarka, M.; Pietryka, I. (Eds.) Problemy Gospodarki Światowej; Polskie Towarzystwo Ekonomiczne, Oddział w Toruniu: Torun, Poland, 2010.

28. Mach, Ł.; Bedrunka, K.; Dąbrowski, I.; Frącz, P. The Relationship between ROP Funds and Sustainable Development-A Case Study for Poland. Energies 2021, 14, 2677. [CrossRef]

29. Strategia Rozwoju Kraju 2020-Aktywne Społeczeństwo, Konkurencyjna Gospodarka, Sprawne Państwo; Dziennik Urzędowy Rzeczypospolitej Polskiej “Monitor Polski” poz. 882: Warsaw, Poland, 2012.

30. Umowa Partnerstwa-Programowanie Perspektywy Finnasowej 2014-2020; Ministerstwo Funduszy i Polityki Regionalnej: Warsaw, Poland, 2020.

31. EUROSTAT. Available online: https:/ / ec.europa.eu/regional_policy/en/newsroom/news/2019/03/03-06-2019-poland-madethe-most-of-cohesion-policy-funds-in-2007-13 (accessed on 8 August 2021).

32. Gaub, F.; Boswinkel, L. The Geopolitical Implications of the COVID-19 Pandemic; Policy Department for External Relations, European Parliament: Brussels, Belgium, 2020.

33. European Economic Forecast. Available online: https://ec.europa.eu/commission/presscorner/detail/en/SPEECH_21_3546 (accessed on 8 August 2021).

34. Adamowicz, E.; Dudek, S.; Konat, G.; Majchrzak, K.; Rtuszny, E.; Walczyk, K. Koniunktura gospodarcza w Europie SrodkowoWschodniej w dobie Epidemii. Rap. SGH Forum Ekon. 2020, 61. [CrossRef]

35. Staniszewski, R. Polish Economy in Quarantine-Analysis of Economic and Social Indicators as Well as Formal and Legal Solutions Related to Counteracting COVID-19. Available online: Researchgate.net/publication/345505106 (accessed on 1 June 2021).

36. Sapir, A. Why has COVID-19 hit different European Union economies so differently? Policy Contrib. 2020, 18, 1-13.

37. Boin, A.; Longe, M.; Luesinek, M. Learning from the COVID-19 crisis: An initial analysis of national responses. Policy Des. Pract. 2020, 3, 189-204. [CrossRef]

38. Arbolino, R.; Di Caro, P. Can the EU funds promote regional resilience at time of Covid 19? Insights from the Great Recession. J. Policy Model. 2021, 43, 109-126. [CrossRef]

39. Van der Ven, H.; Yixian, S. Varieties of Crises: Comparing the Politics of COVID-19 and Climate Change. Glob. Environ. Polit. 2021, 24, 1-10.

40. Cheval, S.; Mihai, A.C.; Goorgiadis, T.; Mathew, H.; Piticar, A.; Legates, D.R. Observed and Potential Impact of COvid-19 Pandemic on the Environment. Int. J. Environ. Res. Public Health. 2020, 17, 4140. [CrossRef] [PubMed]

41. Dane Statystyczne. Available online: https:/ / cohesiondata.ec.europa.eu/2014-2020/ESIF-2014-2020-FINANCES-PLANNEDDETAILS/e4v6-qrrq)\%0A\%0A (accessed on 1 June 2021).

42. Regulation (EU) 2020/558 of the European Parliament and of the Council of 23 April 2020 amending Regulations (EU) No 1301/2013 and (EU) No 1303/2013 As Regards Specific Measures to Provide Exceptional Flexibility for the Use of the European Structural and Investments Funds in Response to the COVID-19 Outbreak, Official Journal of the European Union. Available online: https:/ / eur-lex.europa.eu/eli/reg/2020/558/oj (accessed on 10 May 2021). 